\title{
Measurement of Glomerular Filtration Rate by Free Vitamin $\mathbf{B}_{12}$ Clearance
}

\author{
Koji Hattori, Tatsuo Shiıgai, Yukihito Minato and Hitoshi Iwamoto
}

\begin{abstract}
We determined the vitamin $B_{12}$ clearance using an ultrafiltration technique and assessed whether the clearance of this vitamin $B_{12}$ could be used to estimate the glomerular filtration rate (GFR). Fourteen subjects ( 5 had renal disease, 7 had diabetes mellitus, one had liver cirrhosis and one had cholelithiasis) divided into two groups were studied (group 1, 5 patients without vitamin $B_{12}$ preloading; group 2,9 patients with vitamin $B_{12}$ preloading). Vitamin $B_{12}$ clearance was significantly correlated with inulin clearance $(r=0.81, p<0.001)$ in group 1; group 2 showed an even better correlation $(r=0.94, p<0.001)$ with the presaturated vitamin $B_{12}$ binding protein. In group 2 , the mean inulin and vitamin $B_{12}$ clearance values did not differ significantly $(40.3 \pm 13.6 \mathrm{vs} 48.2 \pm 17.2 \mathrm{ml} / \mathrm{min})$, but there was a significant difference between mean inulin and creatinine clearance $(40.3 \pm 13.6 \mathrm{vs} 64.9 \pm 19.9 \mathrm{ml} / \mathrm{min}, \mathrm{p}<0.05)$. In conclusion, vitamin $B_{12}$ clearance appears to be a more reliable method of estimating GFR than creatinine clearance.
\end{abstract}

(Internal Medicine 32: 194-196, 1993)

Key words: inulin clearance, creatinine clearance

\section{Introduction}

The clearance of inulin and creatinine are the parameters most widely used for the measurement of the glomerular filtration rate (GFR). However, assessment of inulin clearance is a laborious method for clinical use, and creatinine clearance does not provide an adequate estimate of the GFR (1), especially in glomerulopathic patients (2).

Since Watkin et al (3) reported that the renal clearance of free vitamin $B_{12}$ is similar to that of inulin, several reports $(4-8)$ have indicated the usefulness of vitamin $\mathrm{B}_{12}$ clearance as a tool for the estimation of the GFR, in studies using radioactive vitamin $\mathrm{B}_{12}$.

In the present study, we determined the vitamin $B_{12}$ clearance by an ultrafiltration technique and assessed whether it could be used to estimate the GFR.

\section{Patients and Methods}

\section{Patients}

Fourteen subjects described below were studied. They were divided into two groups: group 1 consisted of five patients without vitamin $B_{12}$ preloading, and group 2 consisted of nine patients with vitamin $B_{12}$ preloading.
Full informed consent of all subjects was obtained prior to the study and the study was approved by the regional ethics committee.

\section{Group 1}

The simultaneous renal clearance of creatinine, inulin, and vitamin $B_{12}$ was measured in five patients (4 males and 1 female). Four patients had diabetes mellitus and one had liver cirrhosis. Their mean age was 59 years, ranging from 43 to 75 years. After an overnight fast, the morning urine was discarded, and then a water load $(10 \mathrm{ml} / \mathrm{kg})$ was given before starting the procedure. They were given $0.1 \mathrm{ml}$ of 1:1,000 epinephrine subcutaneously and then received $500 \mu \mathrm{g}$ of vitamin $\mathrm{B}_{12}$ subcutaneously at the same site, in order to maintain a constant blood level of vitamin $\mathrm{B}_{12}$ by retarding its absorption. A priming dose of inulin $(50 \mathrm{mg} / \mathrm{kg})$ was given intravenously followed by continuous infusion at a rate calculated to maintain the plasma inulin concentration constant at $25 \mathrm{mg} / \mathrm{dl}$. After a 60 -min equilibration period, three clearance determinations were performed over $30 \mathrm{~min}$ each. Urine samples were collected by voluntary voiding and blood samples were taken at the mid point of each clearance period.

From the Department of Internal Medicine, Toride Kyodo General Hospital, Ibaraki

Received for publication July 22, 1992; Accepted for publication January 12, 1993

Reprint requests should be addressed to Dr. Koji Hattori, Department of Internal Medicine, Toride Kyodo General Hospital, 5901-1, Terada, Toride-shi, Ibaraki 302, Japan 


\section{Group 2}

Group 2 consisted of four males and five females, with a mean age of 59 years (range: $41-72$ years). Five patients had renal disease, three patients had diabetes mellitus, and one patient had cholelithiasis. After an overnight fast, the first urine was discarded, and then a water load $(10 \mathrm{ml} / \mathrm{kg})$ was given as with group 1 . After being given $2,000 \mu \mathrm{g}$ of vitamin $B_{12}$ intravenously, the subjects received $0.1 \mathrm{ml}$ of $1: 1,000$ epinephrine and $1,000 \mu \mathrm{g}$ of vitamin $\mathrm{B}_{12}$ subcutaneously, and two clearance determinations of $60 \mathrm{~min}$ each were performed. Urine samples were collected by voluntary voiding and blood samples were taken at the midpoint of each clearance period, as in group 1.

\section{Methods}

1. Creatinine

Serum and urinary creatinine concentrations were measured colorimetrically by the modification of the manual Jaffe method using an autoanalyzer (Hitachi 736; Hitachi Ltd.) (9).

2. Inulin

Inulin clearance was measured by the anthrone method (10). Briefly, $500 \mathrm{ml}$ of concentrated sulfuric acid was added to $200 \mathrm{ml}$ of water, and $1.4 \mathrm{~g}$ of anthrone was dissolved. Protein-free plasma filtrates were prepared by adding $1 \mathrm{ml}$ of $10 \%$ trichloroacetic acid (TCA) to $0.1 \mathrm{ml}$ of heparinized plasma. Protein-free urines were prepared by adding $2 \mathrm{ml}$ of $10 \%$ TCA to $0.02 \mathrm{ml}$ of urine. Then, $4 \mathrm{ml}$ of anthrone reagent was added to $0.1 \mathrm{ml}$ of prepared sample, and the mixture was incubated in a water bath at $37^{\circ} \mathrm{C}$ for $50 \mathrm{~min}$. The optical density of the incubated mixture at $630 \mathrm{~nm}$ was calculated by an inulin standard solution.

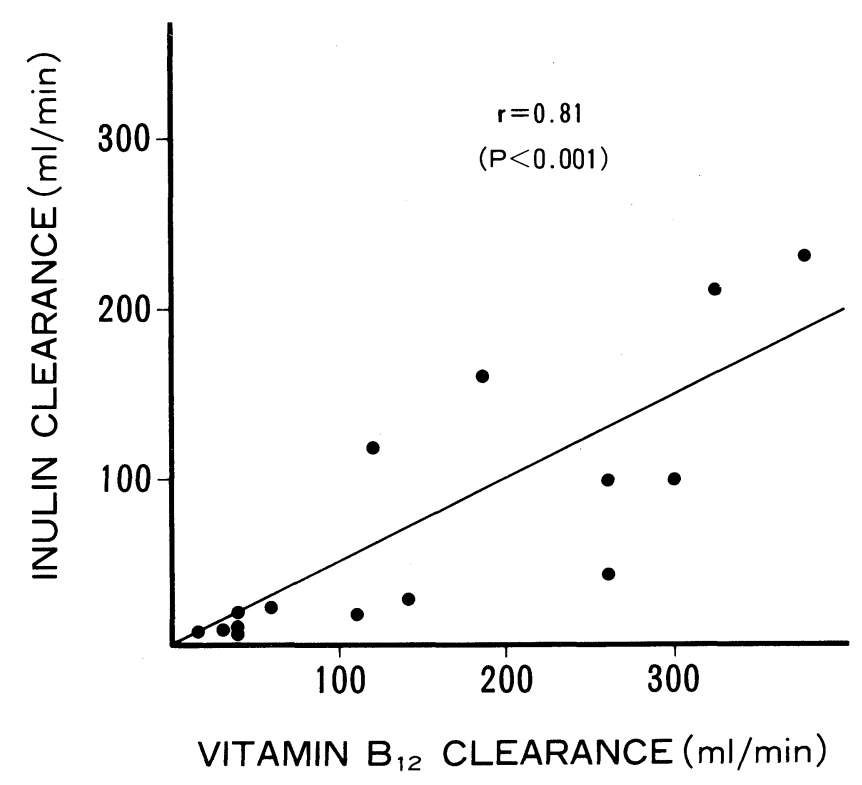

Fig. 1. Correlation between vitamin $B_{12}$ clearance and inulin clearance in subjects without vitamin $\mathrm{B}_{12}$ preloading.

\section{Vitamin $B_{12}$}

Serum $(1 \mathrm{ml})$ was subjected to ultrafiltration for $20 \mathrm{~min}$ at $3,000 \times \mathrm{g}$, using an ultrafiltration membrane (Centricut, Kurabou, Osaka, Japan) that only allowed the passage of molecules with a mol wt $<10,000$. Free vitamin $\mathrm{B}_{12}$ levels in the filtered samples were measured by a competitive protein binding assay (Ciba.Corning, USA). Free vitamin $B_{12}$ in the urine was also measured as it was in the serum after centrifugation for $5 \mathrm{~min}$ at $1,500 \times \mathrm{g}$.

The preliminary experiment with free ${ }^{57} \mathrm{Co}$-vitamin $\mathrm{B}_{12}$ demonstrated that the percentage of recovery of vitamin $\mathrm{B}_{12}$ in this assay was $81.7 \pm 1.5 \%$ (mean $\pm \mathrm{SEM}$ ) and the coefficient of variation was $2.4 \%$. Values were expressed as the mean \pm SEM. Statistical analysis was performed by Student's $t$-test, and results were considered significant at $\mathrm{p}<0.05$.

\section{Results}

\section{Serum vitamin $B_{12}$}

The serum vitamin $B_{12}$ level did not change significantly between the first and third clearance periods in group $1(1,165 \pm 377$ vs $1,293 \pm 431 \mathrm{pg} / \mathrm{ml})$ and between the first and second periods in group $2(153,896 \pm 20,478$ vs $144,823 \pm 23,231 \mathrm{pg} / \mathrm{ml})$.

\section{Relationship between inulin and vitamin $B_{12}$ clearance}

In group 1 , vitamin $B_{12}$ clearance was correlated significantly with inulin clearance $(r=0.81, p<0.001)$ (Fig. 1). In group 2 with vitamin $B_{12}$ preloading, there was still a significant correlation between vitamin $B_{12}$ clearance and inulin clearance $(r=0.94, p<0.001)$

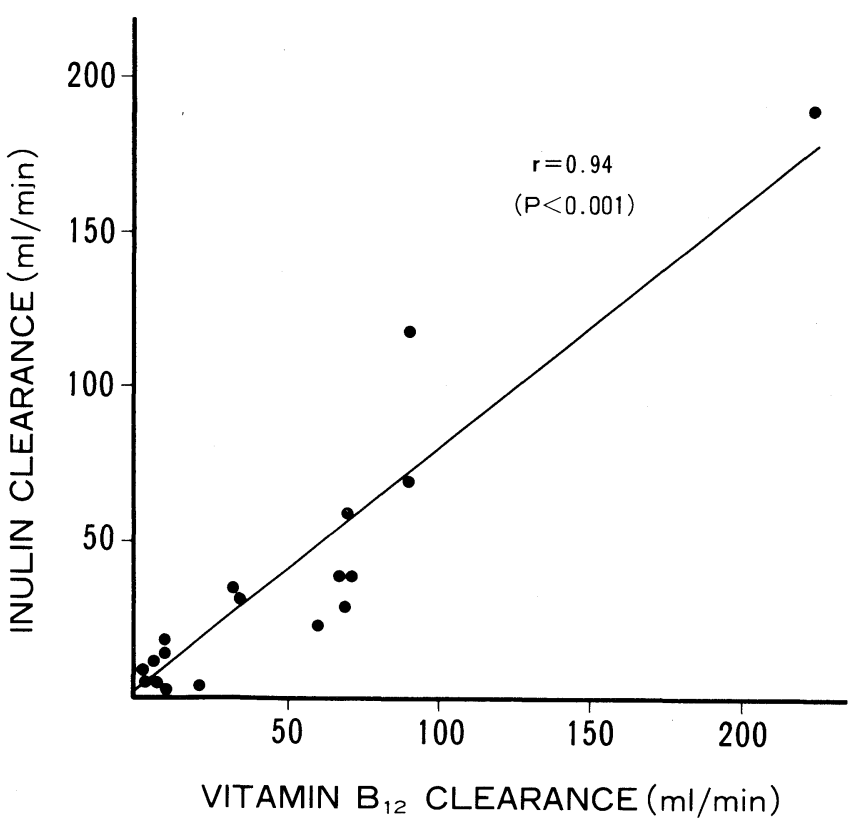

Fig. 2. Correlation between vitamin $\mathrm{B}_{12}$ clearance and inulin clearance in subjects with vitamin $\mathrm{B}_{12}$ preloading. 


\section{HATTORI et al}

Table 1. Comparison of the Mean Vitamin $\mathrm{B}_{12}$, Inulin, and Creatinine Clearances in Subjects with Vitamin $\mathrm{B}_{12}$ Preloading*

\begin{tabular}{lccc}
\hline & $\begin{array}{c}\text { Vitamin } \text { B }_{12} \\
\text { clearance }\end{array}$ & Inulin clearance & $\begin{array}{c}\text { Creatinine } \\
\text { clearance }\end{array}$ \\
\hline 1 & 2 & 9 & 19 \\
2 & 5 & 13 & 12 \\
3 & 3 & 5 & 9 \\
4 & 72 & 41 & 71 \\
5 & 64 & 27 & 55 \\
6 & 81 & 89 & 117 \\
7 & 33 & 33 & 70 \\
8 & 7 & 13 & 25 \\
9 & 167 & 133 & 205 \\
\hline Mean & 48.2 & 40.3 & 64.9 \\
SEM & 17.2 & 13.6 & 19.9 \\
\hline
\end{tabular}

* Each value is the average of two clearance periods. There is a significant difference between inulin and creatinine clearance $(\mathrm{p}<0.05)$.

(Fig. 2).

Comparison of vitamin $B_{12}$, inulin, and creatinine clearance

In group 2 , the inulin, vitamin $\mathrm{B}_{12}$, and creatinine clearances were all compared. The mean inulin and vitamin $B_{12}$ clearance data of the nine patients did not differ significantly $(40.3 \pm 13.6$ vs $48.2 \pm 17.2 \mathrm{ml} / \mathrm{min})$, but there was a significant difference between the mean inulin and creatinine clearance values $(40.3 \pm 13.6$ vs $64.9 \pm 19.9 \mathrm{ml} / \mathrm{min}, \mathrm{p}<0.05$ ) (Table 1 ).

\section{Discussion}

Inulin and creatinine clearance are generally used for the estimation of the GFR. Because inulin is freely filtered at the glomerulus but not acted on by the tubules, inulin is believed to be the ideal marker for determining GFR. Although there are variations in inulin clearances measured in a given individual over time and diurnal variations (11), the inulin clearance has become the standard method for estimation of the GFR. However, the method is too laborious for routine use. The endogenous creatinine clearance is a simple method for estimation of the GFR, but it does not provide adequate information, especially in patients with renal insufficiency (2).

In this study, we assessed a simple method for the estimation of the GFR using the free vitamin $B_{12}$ clearance. Vitamin $B_{12}$ is firmly bound by plasma proteins in physiologic amounts and is not filtered by the glomeruli. Thus, only free vitamin $B_{12}$ can be excreted by the kidneys on the basis of glomerular filtration $(4,5)$, and the vitamin $B_{12}$ clearance has been shown in several reports $(6-8)$ to correlate with the inulin clearance. At low levels of serum vitamin $B_{12}$, the error in estimating vitamin $B_{12}$ is sufficiently large to warrant the inference that the urinary clearance of vitamin $B_{12}$ would be equivalent to the inulin clearance (3); we obtained a better correlation between the vitamin $B_{12}$ and inulin clearances after presaturation of vitamin $B_{12}$ binding protein in group 2.

The prior injection of a small dose of epinephrine retarded the absorption of vitamin $\mathrm{B}_{12}$, and allowed a constant serum vitamin $\mathrm{B}_{12}$ level to be maintained during the study by a single subcutaneous injection of the vita$\min$. The small dose of epinephrine did not produce any symptoms and was unlikely to affect renal function (12). This method required no constant infusion of vitamin $\mathrm{B}_{12}$. Moreover, as an ultrafiltration technique was used to measure the free vitamin $\mathrm{B}_{12}$ level (13), there was no need to handle radioactive material or to expose the subjects to radiation. Assessment of the vitamin $B_{12}$ clearance following a single subcutaneous injection of vitamin $\mathrm{B}_{12}$ with epinephrine appears to be a simple and useful method for the estimation of the GFR.

\section{References}

1) Levey AS, Perrone RD, Madias NE. Serum creatinine and renal function. Ann Rev Med 39: 465, 1988.

2) Shemesh O, Golbetz H, Kriss JP, Myers BD. Limitations of creatinine as a filtration marker in glomerulopathic patients. Kid Int 28: 830, 1985.

3) Watkin DM, Barrows CH Jr, Chow BF, Shock NW. Renal clearance of intravenously administered vitamin $B_{12}$. Proc Soc Exp Biol Med 107: 219, 1961.

4) Nelp WB, Wagner $\mathrm{HN}$ Jr. Use of radioactive vitamin $B_{12}$ to measure the glomerular filtration rate (GFR). J Nuclear Med 4: 216, 1963.

5) Nelp WB, Wagner HN Jr, Reba RC. Renal excretion of vitamin $\mathrm{B}_{12}$ and its use in measurement of glomerular-filtration rate in man. J Lab Clin Med 63: 480, 1964.

6) Breckenridge A, Metcalfe-Gibson A. Methods of measuring glomerular-filtration rate: A comparison of inulin, vitamin- $B_{12}$, and creatinine clearances. Lancet 2: 265, 1965.

7) Cutler RE, Glatte H. Simultaneous measurement of glomerular filtration rate and effective renal plasma flow with ${ }^{57} \mathrm{Co}$-cyanocobalamin and ${ }^{125}$ I-Hippuran. J Lab Clin Med 65: 1041, 1965.

8) Patterson RM, Ray CT. Studies of the applicability of cobalt 57 labelled vitamin B12 (CoB12) for measuring glomerular filtration rate (GFR). Clin Res 13: 80, 1965

9) Chasson AL, Grady HJ, Stanley MA. Determination of creatinine by means of automatic chemical analysis. Am J Clin Pathol 35: 83, 1961.

10) Davidson WD, Sackner MA. Simplification of the anthrone method for the determination of inulin in clearance studies. J Lab Clin Med 62: 351, 1963.

11) Schuster VL, Seldin DW. Renal clearance. in: The Kidney, Seldin DW, Giebisch G, Eds. Raven Press, New York, 1992, p. 943.

12) Israelit $\mathrm{AH}$, Long DL, White MG, Hull AR. Measurement of glomerular filtration rate utilizing a single subcutaneous injection of ${ }^{125}$ I-iothalamate. Kid Int 4: 346, 1973.

13) Davies AG, Leftley JW. Vitamin $B_{12}$ binding by microalgal ectocrines: dissociation constant of the vitamin-binder complex determined using an ultrafiltration technique. Marine Ecology Progress Series 21: 267, 1985. 